\title{
Implementation of Attributive and Delegative Authority of Sub District Head in the Local Government Procedures
}

\author{
Imam Wicaksono ${ }^{1}$, Amalia Diamantina ${ }^{2}$ \\ 1 Postgraduate Study, Faculty of Law, Universitas Diponegoro, Indonesia \\ imamwicaksono0077@gmail.com \\ 2 Faculty of Law, Universitas Diponegoro, Indonesia \\ amaliadiamantina.undip@gmail.com
}

\begin{abstract}
Introduction to The Problem: The authority of Sub District Head in Gringsing sub district came from attributive sources through Law No. 23 of 2014 concerning Local Government and delegative sources through the Regulation of Batang No. 77 of 2015. After the regulation was enacted, the authority of Sub District Head both attributively and delegatively changed, its position as a regional leader also changed.

Purpose/Objective Study: The purpose is to know the implementation of attributive and delegative Sub District Head's authority by looking at the regulations both in the laws and regulations below it.
\end{abstract}

Design/Methodology/Approach: This research is an empirical juridical legal research. In empirical legal research, identification and law are conceptualized as a real social institution. The focus of this research is limited to Gringsing District, Batang Regency, Central Java.

Findings: Referring to the attributive authority of Sub District Head after Law No. 23 of 2014 concerning Local Government, in general, there is no meaningful authority inside. Instead of being regulated in the provisions of the legislation, the material is more on the delegation of authority from the Regent (Bupati), which in this case is enough by delegative way. Moreover, after Law No. 6 of 2014 concerning Villages where the position of the village is increasingly strengthened administratively and politically are increasingly independent thus the Sub District Head's authority is more narrowed.

Paper Type: Research Article

Keywords: Sub District Head; Local Government; Attributive; Delegative

\section{Introduction}

"Indonesia is a state of law", as stated in Article 1 paragraph (3) of the 1945 Constitution of the Republic of Indonesia. The principle of legality is a rule of law which is often formulated in a specific manner, that every action in the administration of government must follow the provisions of the regulations legislation. Therefore, in the implementation of governance, it is necessary to guarantee the protection of 


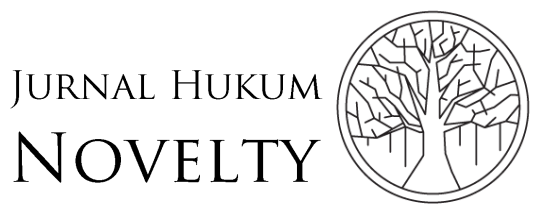

Volume 10, Issue 02, 2019, pp. 179-193

people's rights and the principle of legality is used as a reference for legitimacy as an action or action to carry out an autonomous local government.

The system of governance in Indonesia as sees in the explanation of the 1945 Constitution, that Indonesian region is divided into the number of regional forms namely the provincial, and the provincial are divided into regency area, and regency area are divided into smaller region namely sub district. Furthermore, as contained in Article 18 paragraph (1) of the 1945 Constitution of the Republic of Indonesia, which reads, "The Unitary State of the Republic of Indonesia is divided into provincial regions and the provincial areas are divided into regencies and cities, each province, regency, and city have local government that regulated by law."

Then it is stated in Article 18 paragraph (2) of the 1945 Constitution that, "Provincial, regency, and city local governments regulate and manage their government affairs according to the principle of autonomy and assistance duty." The above provisions mandate that local government is an autonomous form of government in the constitutional system of the Republic of Indonesia (Yuswalina \& Budianto, 2016). In Article 18 paragraphs (1) and (2) of the 1945 Constitution of the Republic of Indonesia, it is mandated that each of these regions divided into smaller regions and have a separate governmental affair and their government procedure shall be regulated by the Act as a manifestation of the principle of legality.

Looking at Article 5 letter (a) of Law No. 30 of 2014 concerning Government Administration, the government procedures must refer to the principle of legality as an act of implementing an autonomous local government. The idea of democracy and the rule of law is closely related to the principle of legality, so the idea of democracy demands every form of law as well as various decisions to be approved by the people's representatives by paying attention to justice and the interest of the people.

In Article 221 paragraph (1) of Law No. 23 of 2014 concerning Local Government, explains that a sub district is a "regency or city region forming a sub-district to improve the coordination of government administration, public services, and empowerment of rural or urban society." In the implementation of local autonomy policy, trying to boost a change in structure, function, and culture in all arrangements of local governance, thus a change is expected regarding the position, authority, duties, and functions of the Sub District Head.

In the explanation of Law No. 23 of 2014 concerning Local Government, the procedure creates a pattern of handover or delegation of Sub District Head's authority is very dependent on the delegation from the Regent or Mayor, to handle autonomous government affairs and the implementation of general government, therefore this has an impact on optimizing the role and performance of the Sub District Head in an effort to maximize the effectiveness of services to the public. 
P-ISSN: $1412-6834$

E-ISSN: 2550-0090

Article 226 paragraph (2) of Law No. 23 of 2014 concerning Local Government, explains that "the delegation of authority of regents/mayors as referred to in paragraph (1) is based on mapping public services in accordance with the characteristics of the sub-district and/or the needs of the society in the sub-district itself." Nowadays, the status of the sub-district is a regional apparatus regency or city as contained in Article 209 paragraph (2) of Law no. 23 of 2014 concerning Local Government which reads, "District/city regional apparatus consists of the local secretariat, DPRD secretary, Inspectorate, Service, Agency and District."

Regarding the mechanism for the distribution of the functions of the local administration, following the concept of the residual function that submitted to the city or regency level, while for the central and provincial affairs, it is determined specifically and clearly. Seeing the scope of the remaining functions handed over to the city or district is very broad, this can make the impression of the city or district pouring on the principle of broad autonomy, while the limited autonomy is at the provincial level (Yusdianto, 2015).

The sub-district specifically leads to decentralized management or a form of decentralization in dealing with the implementation of local government (Nugroho, Supriyono, Domai, \& Muluk, 2019). Viewed from the perspective of public administration, the delegation of authority from the Regent or Mayor to the Sub District Head, and the delegation of some tasks from the Sub District Head to the Village is the existence of the region's needs by the regional potential. The delegation is intended to create effectiveness and efficiency in managing the local government while improving public services in the region. So far, the implementation of several existing authorities is still concentrated in the Regency or City. This can cause problems, such as in the implementation of Regency or City Government still has a heavy workload, then the service function to the society will be less optimal. The authority that is too large, the Regency or City government, which is designed to distribute its authority to the organs of government under it in order to realize the implementation of local government and public services effectively and efficiently (Kusuma, 2016).

In terms of the sub district's authority over the village, the administration has also changed, not only because of the enactment of Law no. 23 of 2014 concerning Local Government, but also through Law No. 6 of 2014 concerning Villages. This changing bureaucratic map certainly requires some adjustments to the government in the sub district area, especially in the aspect of attributive and delegative authority.

In this research the writer took one of the samples or research objects, that is the sub district of Gringsing, Batang regency. The Sub District Head in implementing his role as a head of sub district administration. Especially in carrying out the duty and authority of the sub district head and its problem after the enactment of Law no. 23 of 2014 concerning Local Governments and their authority over villages after Law No. 


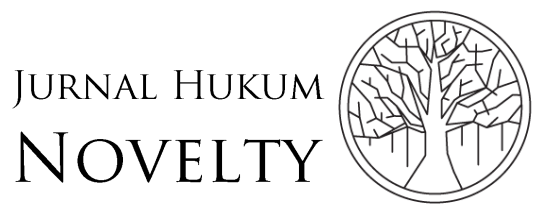

Volume 10, Issue 02, 2019, pp. 179-193

6 of 2014 concerning Villages. Based on these, the issues raised are; 1) How is the implementation of attributive and delegative authority of the Sub District Head in the local government procedures? 2) What are the obstacles and efforts of the Sub District Head in the implementation of local government procedures?

\section{Methodology}

This research is an empirical juridical legal research. In empirical legal research, identification and law are conceptualized as a real social institution that linked to another variable. Law as a social phenomenon is empirical which can be studied as an independent variable, it will have an effect and impact on various aspects of social life (Amiruddin \& Asikin, 2010). The empirical juridical approach method can describe the object that studied systematically, and then the juridical approach in this study looks at in terms of legal norms and legislation in accordance with real or concrete issues. The empirical approach in this study is to analyze that law is not a set of empirical regulations, but the law is seen as people's behavior related to economic, political, social, and cultural aspects. The implementation of local government has an influence and effect, namely in the implementation of development and supervision of the local government procedures, as well as Sub District Head's attributive and delegative authority must be based on the principle of legality or applicable law. This research is limited to regions or locations in Gringsing Sub District, Batang Regency, Central Java, Indonesia.

\section{Results and Discussion}

Implementation of Attributive and Delegative Authority of Subdistrict Head (Camat) in the Local Government Procedures

Referring to Article 1 paragraph (3) of the 1945 Constitution that said, "Indonesia is a state of law," in the principle of legality, that the source of governmental authority originates from the laws and regulations which already applied. Theoretically, the government authority that comes from legislation can be obtained through three ways, namely: Attributive, Delegative, and Mandate. The attributive is Giving the authority of local government procedures from lawmakers to other government organs. An attributive pattern through the granting of new governmental authority by a provision in the legislation. This authority is usually called the inherent authority of the law and became the responsibility of the authorized recipient. Delegative is delegation of government authority from one governmental organ to another governmental organ. Delegation concerns the delegation of authority that already exists. And the authority delegated will be the responsibility of the authorized recipient. Mandates occur when government organs permit their authority to be carried out by other organs on their behalf. But this authority remains the responsibility of the authority giver and reports it to the authority giver (Ridwan, 2006). 
P-ISSN: $1412-6834$

E-ISSN: 2550-0090

The government in general consists of the local procedures affairs and the rest of the affairs which are not local, which are usually called central affairs, national affairs or general affairs. Government procedures that held in the region are not only limited to local affairs or central affairs but both. The role of civil servants in Indonesia is very important in the efforts of government procedures and national development because civil servants themselves are elements of the state apparatus that can carry out government and development in achieving national goals (Jaffisa, Kadir, \& Harahap, 2017).

The flexibility and adaptability of local government organizations are needed, so they can quickly respond to the ever-changing challenges, along with the dynamics of the people in each region. Therefore, in government procedures, the need for local apparatus organizations in each region is not always the same. In the apparatus sector, the organizational structure requires appropriate brainpower to enable the optimization of the work of the organization itself. Therefore, five strategic aspects in developing apparatus resources need to be addressed including recruitment, payroll, education and training, career promotion and government ethics (Labolo, 2015).

After the emergence of Law No. 23 of 2014 concerning Local Government, today the Sub District Head has the character to coordinate activities and carry out part of the authority of the Regent. Rusmanto as the Sub District Head of Gringsing stated that the sub-district was only a sub district work area. The Sub District Head is no longer the head of the government area, and then the Sub District Head no longer has the power as the Head of the Region, even the Village Head is also not a direct subordinate of the Sub District Head, the village head is stronger and has power because he is directly elected by the people through Village Head Election (i.e. Pemilihan Kepala Desa, abbreviated as Pilkades), so the Sub District Head relationship with the Village Head is only coordination, coaching, and facilitation. Regarding the position of the Sub District Head in the local government procedures in Gringsing Sub District, the Sub District Head is not the Head of the Local Government and the sub district is not the power of the Sub District Head in the local government procedures, but the Sub District Head now has the duty to coordinate activities and the Sub District only becomes the scope of the Camat's working area in the administration of the Local Government (As interview, Rusmanto, 2018). Even the portion of this authority is reduced by the emergence of Law no. 6 of 2014 concerning Villages where the provisions of Article 1 paragraph 1 state that the Village has the authority to regulate and manage government affairs, the interests of local communities based on community initiatives, original rights, and/or traditional rights that are recognized and respected in the system of government of the Unitary Republic of Indonesia.

In legal terms, in the Indonesian context, a restatement of principles or principles of good governance as bestursnormen (norms or rules of government) has been carried out through Law Number 30 of 2014 concerning Government Administration. This was reflected in, first, the purpose of the enactment of Law No. 30 of 2014 as a legal 


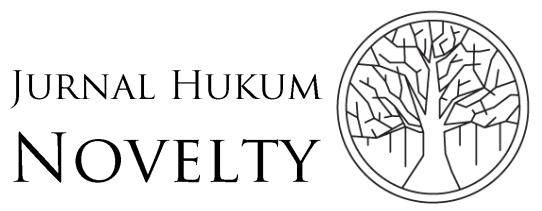

Volume 10, Issue 02, 2019, pp. 179-193

basis for government officials, the public, and other parties relating to government administration in order to improve the quality of government administration, contained in Article 2 of Law No. 30 of 2014. Second, the aim of enacting Law No. 30 of 2014 is to realize orderly government administration, legal certainty and prevent abuse of authority, ensure accountability of government officials, provide a guarantee of legal protection to the public and government officials, carry out in accordance with applicable laws and regulations and implement the principles good governance to be able to provide optimal services to the community, as contained in Article 3 of Law no. 30 of 2014 (Kurnia, Rauta \& Siswanto, 2018).

People are free to criticize the government if the services they receive are not as expected. As stated in Masnurdiansyah (2016); nationally most of the reports that people complain about are poor public services in local governments (Ella \& Utami, 2017). Sub district as a regional instrument that has duties and authority must pay attention to all matters relating to the welfare of the society. One of the concerns of the District Government in the welfare of the society is that there are strict actions from the Regency Government on the quality of services and education, especially in terms of providing adequate educational facilities and infrastructure for those who need them in order to create good public services and good learning (Sitanggang \& Husin, 2014).

Sub District Head as the executing element in the sub district area, the sub district itself is part of the elements of the regency or city government, in carrying out its duties and the authority to obtain delegation or some of the affairs of the regent or mayor's authority to handle some local autonomy matters. The Sub District Head is the leader and coordinator in order to organize a local government in the sub-district work area and carry out general government tasks. The sub-district is currently located as a regional apparatus of regency, which in local government procedures has a portion of the local autonomy and governance functions as regulated in Law no. 23 of 2014 concerning Local Government.

However, in the implementation of local government procedures, the implementation of local government autonomy needs the principles that must be carried out as follows: First, Decentralization is the transfer of a portion of government affairs from the center to local governments in order to manage and regulate their area. But not all affairs can be given by the central government to local governments. Giving of government affairs to the executive branch with the intention that the local government can establish services following the functions, thus local regulations can be made by the local government, the local legislative body or the Local Representative Council (DPRD). The existence of a local legislative body and regional executive institution that manage their households. Second, Deconcentrating is the delegation of authority from the central government or officials in between (for example, provinces). So, once the central department delegates its authority to the head office officer in the provincial area, or the head office in the province transfers 
the authority to the head office in the district, sometimes sectoral egoism arises because the local government does not know the implementation and it is difficult to monitor it. Third, the Assistance Task, in Dutch is called mede bewind, mede which means to participate or participate, while bewind means to rule or rule. So, the local government participates in managing central government affairs, but then those matters must be accounted to the central government (Syafiie, 2013).

If referring to the provisions of Article 225 paragraph (1) of Law No. 23 of 2014 concerning Local Government, the attributive authority of Sub District Head is more to coordinate government procedures or organs above it to the general public or village government. The Sub District Head based on these provisions has at least 9 main tasks, including; 1). carry out general government affairs as referred in Article 25 paragraph (6); 2). coordinate society empowerment activities; c. coordinate efforts to organize peace and public order; 3 ). coordinate the application and enforcement of Perda \& Perkada; 4). coordinate the maintenance of infrastructure and public service facilities; 5). coordinate the implementation of government activities carried out by the Local Apparatus in the sub district; 6). fostering and overseeing the implementation of Village activities; 7). implement Government Affairs which are the authority of regency/city Region that not implemented by the work unit of regency/city Region in the sub district, and 8). carry out other tasks in accordance with law statutory.

Sub district head as a local apparatus, besides having the task of carrying out government authority based on attributive authority, also has a delegative authority from the regent or mayor to handle part of local autonomy affairs based on regent or mayor regulations, the Sub District Head also carries out general government tasks (Hamidah, 2014). The Sub District Head is very influential on the quality of services to the society in the framework of an orderly procedure of the village administration as its duty to foster and supervise the village administration which is within the scope of Gringsing Sub district.

This focus on the aspects of the Sub district's authority over the village government in the Gringsing area is interesting, although it is no longer has the broad authority as before, but attribute fully the sub district head has authority in the field of guidance and supervision of the village government. The Sub District Head in guiding and supervising the administration of the village administration in Gringsing sub district are as follows (Interview results, Rusmanto, 2018):

First, to provide guidance and supervision of the village administration. In conducting temporary guidance and supervision, if it is associated with an urgent or emergency activity, the Gringsing Sub district conducts a direct survey to the villages regarding, administration, relevant legal basis, and documents to be issued, therefore in the future, if there is a legal product problem can be held accountable in court. Coaching by the Sub District Head to employees or subordinates must be carried out with 


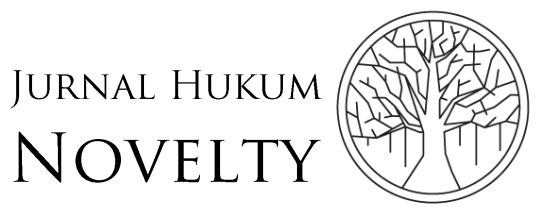

Volume 10, Issue 02, 2019, pp. 179-193

discipline with assignments given following their expertise and avoiding additional overtime hours.

Second, Provide guidance, supervision, facilitation, and consultation in the implementation of village administration. All government employees in Gringsing Sub district are given direction or material related to their work, with the hope that the completion of work under the target and if there is a problem in doing work that is personal or urgent they can make direct contact with their superiors by the subordinate.

Third, provide guidance and supervision of the village head. Guidance given by the Sub District Head to the Village Head is carried out with special coaching, the special coaching is a kind cross-sectoral coaching or so-called (Rakorlinsek) cross-sectoral coordination meetings and supervision which is carried out guided by the applicable Laws, Local Regulations, Local Head Regulation, in the context of maintaining the activities carried out within the corridor or boundary that has been previously determined.

Fourth, provide guidance and supervision of village officials. The guidance referred to how far the Sub District Head is able to conduct and provide guidance on what was done by the village apparatus, both those that not stipulated yet or according to the guidelines, or new things; and supervision is carried out so that all activities can be carried out in accordance with statutory applicable law.

Fifth, Evaluate the implementation of village governance at the sub-district level. Evaluation is aimed at all government employees in the Gringsing Sub district area, carried out to assess, to rectify, to determine the extent of governmental tasks that have been carried out. Seeing services to the society, whether the implementation of government and procedures are in accordance with applicable laws and regulations, therefore the sub-district head needs to evaluate government procedures.

Sixth, Reporting the implementation of coaching and supervision of village administration at the sub-district level to the Regent. The report is carried out in stages, starting with village government reports by the Village Head, and then reporting to the Regent through the Sub District Head. At the reporting stage, a special strategy is needed by socializing with all government employees in the Gringsing Sub district area, with the aim of government tasks, services, and development of the society carried out effectively.

A leader means someone who has the skills and strengths; therefore, he can influence a person or group to carry out certain activities to achieve goals and run effectively and efficiently (Hendriyaldi, 2019). The role of the Sub District Head is to coordinate activities within the sub district area, coordinate development of inter-village governance activities such as direct development, supervision, and facilitation of 
village government procedures, resolve inter-village problems, resolve disputes between villages and maintain harmony in the village.

Success in the implementation of local government procedures and the implementation of national development is inseparable from the participation of civil servants. The position of its role is very important and will have a good impact, the employees are always required to have loyalty and obedience in carrying out their duties and focus all their attention, and mobilize the strength to the maximum and be able to embody national goals (Jaffisa et al., 2017).

Sub District Head in administering the government does not only carry out the attributes that are the attributive or inherent authority of Law Number 23 of 2014 concerning Local Government. However, the Sub District Head also received delegation which was delegative or the Regent authority to the Sub District Head in the Local Government procedures in the Sub district of Gringsing. Delegation of authority from the Regent to the Sub District Head of Gringsing, namely handling licenses through the Integrated District Administrative Service (PATEN). The authority delegated to the Sub District Head is an authority that is not handled by agency offices at the sub-district level, so for matters of governmental authority in the fields of health, agriculture, health which are handled by separate agency offices, such as the education, agriculture and health offices in the Gringsing Sub district area. The sub-district has its own Technical Service Unit (UPTD), thus the affairs are not handled by the Sub District Head (Interview result, Rusmanto, 2018).

Carrying out the tasks of government agencies in the sub district area must be in the sub district corridor. Sub District Head as a regional instrument that has specificity in carrying out its main duties and functions to support the application of the principle of decentralization. Its specialty is the obligation to integrate cultural and social values, create a balance in political, economic and cultural interactions, as well as regional peace and order as a form of people's welfare in order to build the territorial integrity of the region in the sub district. The main task of the Sub District Head, in addition to providing services to society, is also carrying out the task of local development and supervision (Sinaga \& Melianti, 2017).

The transfer of authority from the Regent to the Sub District Head in the Local Government procedures in Gringsing Sub District is contained in Article 3 paragraph (2) letter a of the Regent's Regulation Number 77 of 2015 concerning Amendment to the Regulation of the Regent's Number 3 of 2015 concerning the Delegation of a portion of Government Affairs which become the Authority of the Regent to the sub district in the Batang Regency Government Environment, which reads "The Sub District Head carries out the governmental authority delegated by the Regent to handle a portion of local autonomy matters which includes licensing aspects consisting of: 1) Building construction permit (IMB) for the built up land area up to $100 \mathrm{~m} 2$ for residential buildings and not terraced also not residential areas; 2) 


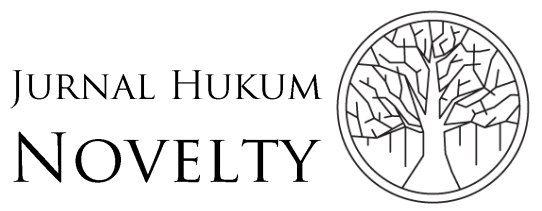

Volume 10, Issue 02, 2019, pp. 179-193

Disturbance licenses for businesses with a small disturbance index within an area up to $500 \mathrm{~m} 2$; 3) Beauty salon business permit; 4) Restaurant business permit for small and medium scale; 5) Billboards permit with criteria: a) Hanging board with installation above shop/stall or yard/yard of business location, b) Banners /screens/banners: with installation location in one sub-district area; c) Posters/stickers/ leaflets: installation in one sub district area. (6) Company registration certificate (TDP) and trading permit (IUP), micro and small; (7) Micro and small business licenses (IUMK)."

Sub District Head of Gringsing in carrying out local government procedures delegated authority from the Regent to handle some local autonomy matters which included licensing, recommendations, coordination, guidance, supervision, facilitation, stipulation and administration. One of them is licensing conducted by the Sub District Head through the Integrated District Administrative Services (PATEN), in the form of a Micro Small Business Permit (IUMK) submitted by prospective business owners, small micro-businesses with a funding scale of 100 million to 500 million, it is sufficient to submit only through the integrated services of the sub district in Gringsing Sub district. By fulfilling the specified requirements, a survey of the correct data is conducted. But for a scale of funds more than 500 million, an environmental permit called the HO (Hinder Ordonantie) permit must be obtained. The approval is required by the Batang Regency Investment Office, if the HO (Hinder Ordonantie) deposit is sufficient, it will be immediately deposited to BPD (Regional Development Bank) in Gringsing Sub district.

For IMB Applicants, submit proposal documents and their completeness to the sub district office. The sub district will verify the documents and the physical feasibility of the building and determine the cost of retribution and issuing IMB permits. In its implementation, several problems occur in the management of IMB. Some problems include vulnerability to data from field survey results and calculation of fees. Several problems often occur in the calculation of retribution fees. Because the records carried out by survey team officers in the field then it could have occurred calculation errors and when an error occurs then the records were transferred to the administrative staff in the office to produce Audit Reports of Inspection Reports (BAP) and calculation of IMB retribution fees (Akbar, Wahyuni, \& Kamil, 2018). Because the truth and data Information is data that has been processed in a form that is more meaningful to recipients who describe the real events, thus it is useful and can be used in the decision-making process for now and in the future (Sudarmaji \& Sari, 2016).

\section{Obstacles and Efforts of the Subdistrict Head in the Implementation of Local Government Procedures}

As explained above, the position of Sub District Head after Law No. 23 of 2019 concerning Local Government, the attributive authority granted to the Sub District Head is no longer as the local head but is limited to administrative activities of government extension. The position of the village through Law No. 6 of 2014 
P-ISSN: $1412-6834$

E-ISSN: 2550-0090

concerning Villages was increasingly strengthened based on an independent and autonomous village.

This certainly has an impact on the efforts and strategies of the Sub District Head in carrying out its performance for the scope of its territory, where in the past the Sub District Head's position as the local head was in charge of the village, today it has shifted to become a village supervisor. Here the Sub District Head's position indirectly acts as an "inspectorate" towards the village.

However, the position of the Sub District Head is still very much expected considering attributively still given authority which not only limited to supervising but also fostering and coordinating across villages in the area. Rusmanto said that the function of the Sub District Head to the village besides supervision also provide direct guidance, coordinating between villages, resolving disputes between villages, facilitating the administration of the village government, and also maintaining harmony in the village (Interview result, Rusmanto, 2018).

To conduct supervision and guidance, the Sub District Head of Gringsing in an emergency conduct a direct survey to the villages regarding administration and legal basis related to documents that have been or will be issued therefore in the future if a legal dispute arises, then it can be justified. The Sub District Head then reports to the Regent regarding aspects of his guidance and supervision. If the village wants to report to the Regent, it must also go through the Sub District Head (Interview result, Rusmanto, 2018).

Related to the authority of the delegation granted by the Regent to the (Interview result, Rusmanto, 2018) through the provisions of Article 3 paragraph (2) letter a Regulation of the Regent of Batang No. 77/2015 concerning Amendment to the Regulation of the Regent of Batang No. 3/2015 concerning the Delegation of part of the Affairs which become the Regent's Authority to the Sub District Head of the Government Batang Regency. In this provision, it is most evident that the delegation of the Regent's authority to the Sub District Head was more on the licensing aspect with the scale of small businesses in his area.

Referring to the provisions of Article 1 paragraph 5 of the Regulation of the Regent of Batang Number 77 of 2015 concerning Amendment to the Regulation of the Regent of Batang Number 3 of 2015 concerning the Delegation of part of the Affairs that become the Authority of the Regent to the Sub-District Head in the District Government of Batang confirms:

"The Sub-District Head is the leader and coordinator of government administration in the region sub district work which in the implementation of its duties obtained delegation of government authority from the Regent to handle some of the functions of regional autonomy, and carry out general tasks of government." 


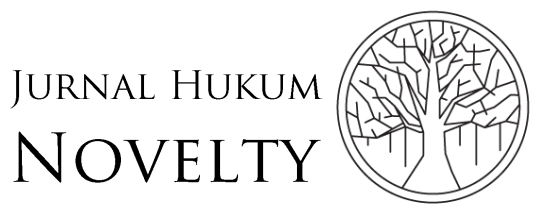

Volume 10, Issue 02, 2019, pp. 179-193

According to these provisions, the position of the Sub District Head as a leader, as well as a coordinator, becomes ambiguous because in this sense the understanding of a leader is different from the coordinator. If the Sub District Head is the leader of his area, then he has the authority to regulate his area independently or at least to the villages below. However, the position of the sub district itself is not a regional leader, but his authority is limited to assisting the Regent from delegating authority for autonomy matters, one of them is the issue of licensing for small or micro-businesses.

In addition to licensing administration, the Sub District Head in Batang regency also given the authority to issue Recommendation Letters and Certificates relating to population administration, as well as letters of introduction for business licensing, and other forms that still within the scope of the sub district area. In this provision, the strategic aspect is directly held by the authority of the Regent, so the Sub District Head is limited to a letter of introduction. This is also actually counterproductive to the Sub District Head concept as a regional leader who has special rights, especially in strategic aspects relating to micro and macro businesses in his area.

Sub District Head in the local government procedure in Gringsing Sub-District, Batang Regency faced several obstacles. The internal obstacles experienced by the Sub District Head is Human Resources (HR) in the Village Government. While the external obstacles experienced by the Sub District Head such as lack of public awareness, lack human resources, lack direction of the relevant activities, lack of competence or understanding of the village head and his instruments in drafting village regulations and many Village Government apparatuses don't understand the development of Science and Technology.

The Sub District Head's effort in dealing with internal obstacles in the Implementation of Local Government Procedures in Gringsing sub district such as; First, coordinate the organization of peace and public order in Gringsing Sub District in order to create peace and public order to make various efforts to anticipate the low Human Resources (HR) in the community by conducting direct coaching with members of the Indonesian National Police and/or Indonesian National Army (TNI) and society leaders who have competence that can solve existing problems in the society in order to create peace and public order.

Second, coordinate the activities of the service agencies in the Gringsing Sub District, such as the Technical Implementation Unit (UPTD) of education, health, agriculture, etc. Sub districts conduct coordination meetings (cross-sectoral coordination meetings) every 3 (three) months to integrate programs from agency offices so they work directly, and every 1 (one) semester the sub-districts evaluate government implementation.

Third, provide guidelines directly to the village officials. Starting from the formation of village regulations to clarification at the sub-district level, then the Sub District Head facilitates the formulation of village regulations and village deliberations. If 
P-ISSN: $1412-6834$

E-ISSN: 2550-0090

obstacles are found in the village government in a state of urgency, then the efforts made are coordination and coaching to come directly to the villages, then the Sub District Head gathers competent people in the village to be briefed according to the problem.

Fourth, the efforts of the Sub District Head for the lack of understanding of the development of Science and Technology (IPTEK), then the Sub District Head conducts socialization through materials on increasing the capacity of the Village Government supported by qualified, capable, utilizing, developing and controlling resource persons Science and Technology and management skills.

Lack of knowledge in understanding work regulations, procedures or policies is the cause of many disciplinary actions. To overcome these actions, the leader must provide input through an orientation program on the employees from the first day to work; unclear rules will also make discipline not run properly. The leader also plays a direct role in the details of the rules that are often violated rationally and what consequences will be given later. Openly inform employees about changes in regulations, procedures, and policies with the aim that employees can know clearly and do not cause disciplinary action (Dohlia, Novera, \& Syamsurizaldi, 2018).

Local governments need the role and creativity in the implementation of local autonomy to manage and develop the region, so in the implementation of local government procedure can not be separated from a coordination to align the extent of the ability of the region to manage, develop their regional potential (Salam, Darmastuti, \& Situmeang , 2016). It is hoped that soon the realization of high quality Human Resources can develop and overcome Science and Technology and management skills. Therefore, in the service of modern society through EGovernment they will be able to build a relationship between the government and the society in local government procedures in public services field, thus it will facilitate access for people efficiently, effectively and economically (Herawati, 2016).

The management and local government procedures in sub district area must be comprehensive at the same time, where the regulations, systems and human resources inside can reach the maximum in every line of government in effectively and efficiently. The authority given to the sub district head both attributively and delegatively will not run well if not supported by the good ability and measured government management following the principles of good governance. Moreover, entering the era of e-government, the government is demanded to provide quickly and openly services.

\section{Conclusion}

Based on the description above, it can be seen that the position of Sub District Head which is actually under the regent but is no longer the head of a region, however, it is limited to the coordinator in helping the Sub District Head in his area. This has an impact on the urgency of the Sub District Head itself as a regional leader and there 


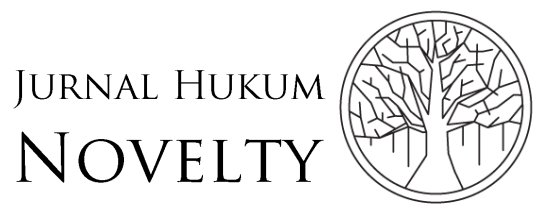

Volume 10, Issue 02, 2019, pp. 179-193
P-ISSN: $1412-6834$

E-ISSN: 2550-0090

has also been a shift to being a regional coordinator. However, the reduced authority does not lose the spirit of the Gringsing Sub District Head's so he will more focused on internal issues and problems therefore he can carry out its duties in Gringsing sub District which is not only the aspect of coordination but also carries out the authority that delegated by the government above it to handle some of the local matters autonomy.

The results of this research have revealed that attributive authority in the context of Sub District Head's authority is no longer urgent, so it must be maximized by giving the authority by the Regent. Sub District Head's dignity as a regional leader must be supported by a more concrete authority not only limited to coordination but also as an organizer of the administration in a more concrete area. Of course, this can be done with the Regent's authority delegation or based on local regulations. The last suggestion, the pattern of Sub District Head development for villages must be clarified in any field with clear indicators of success. The Central Government through the ministries and local governments can sit together to formulate regulations that can encourage the village to develop every potential and administration under the law.

\section{References}

Akbar, F., Wahyuni, A. D., \& Kamil, H. (2018). Pemanfaatan aplikasi web dan mobile sebagai penunjang pengurusan izin mendirikan bangunan kecamatan baso, agam. Jurnal Nasional Teknologi Dan Sistem Informasi, 4(2), 73-80. https://doi.org/10.25077/TEKNOSI.v4i2.2018.73-80

Amiruddin \& Asikin, Z. (2010). Pengantar metode penelitian hukum. Jakarta: Grafindo Persada.

Dohlia, P., Novera, \& Syamsurizaldi. (2018). Pengaruh disiplin kerja dan motivasi kerja PNS pada Kantor Camat di Kabupaten Solok Selatan. JAKP Uurnal Administrasi dan Kebijakan Publik, 3(1), 261-273. https://doi.org/10.25077/jakp.3.3.261-273.2018

Ella, S., \& Utami, I. R. (2017). Sistem informasi penilaian (SIP) Bdg juara: sebuah inovasi untuk meningkatkan pelayanan publik. Jurnal Penelitian Komunikasi, 20(2),189-202. https://doi.org/10.20422/jpk.v20i2.241

Hamidah, U. (2014). Peran kecamatan sebagai perangkat daerah dalam pelayanan pertanahan (studi pada Kecamatan Tanjung Karang Timur). Fiat Justisia, 5(2), 118. https://doi.org/10.25041/fiatjustisia.v5no2.57

Hendriyaldi, H. (2019). Pengaruh gaya kepemimpinan dan budaya organisasi terhadap kinerja pegawai pada Kantor Camat Pangkalan Jambu Kabupaten Merangin. Jurnal Benefita, 1(1), 26-38. https://doi.org/10.22216/jbe.v1i1.3442

Herawati, N. R. (2016). Penerapan e-government dalam mendorong terwujudnya penyelenggaraan pemerintahan yang baik (Studi penelitian Kabupaten/Kota di Jawa Tengah), 13(2), 63-76. Jurnal Ilmu Sosial. Retrieved from https://ejournal.undip.ac.id/index.php/ilmusos/article/view/10296

Jaffisa, T., Kadir, A., \& Harahap, D. (2017). Peranan Camat dalam pengawasan disiplin pegawai negeri sipil di Kantor Kecamatan. Jurnal Administrasi Publik, 7(2), 94- 
106. http://dx.doi.org/10.31289/jap.v7i2.1331

Kurnia, T. S., Rauta, U., \& Siswanto, A. (2018). E-government dalam penyelenggaraan pemerintahan daerah di Indonesia. Masalah-Masalah Hukum, 46(2), 170-181. Retrieved from https://ejournal.undip.ac.id/index.php/mmh/article/view/14608

Kusuma, R. E. (2016). Pelaksanaan pendelegasian wewenang bupati kepada camat dalam penyelenggaraan Pemerintahan Daerah. Yuridika, 28(2), 243-268. https://doi.org/10.20473/ydk.v28i2.1883

Labolo, M. (2015). Dialektika ilmu pemerintahan. Bogor: Ghalia Indonesia.

Nugroho, A., Supriyono, B., Domai, T., \& Muluk, M. . K. (2019). Realizing the effectiveness of districts administration at the Government of Pandeglang Regency, Banten Province, Indonesia. Journal of Public Administration Studies, 1(4), 19-25. http://dx.doi.org/10.21776/ub.jpas.2019.004.01.4

Ridwan. (2006). Hukum administrasi negara. Jakarta: Rajawali Perss.

Salam, S., Darmastuti, S., \& Situmeang, N. (2016). Political autonomy and foreign investment: the analytical review of community empowerment in the concession of PT Newmont Nusa Tenggara/PT NTT (Sumbawa). Proceedings of International Conference on Indonesian Social and Political Enquiries: Localizing Globalization, 1(1), 107-120. Retrieved from http://eprints.upnyk.ac.id/12573/1/PROCEEDINGS-ICISPE-

2016.pdf\#page $=111$

Sinaga, D. M. C., \& Melianti, Y. (2017). Pelaksanaan PP RI No.19/2008 sebagai acuan kinerja Camat pada aspek pemerintahan dan pendidikan. JPPUMA: Jurnal Ilmu Pemerintahan Dan Sosial Politik Universitas Medan Area, 3(1), 37-48. Retrieved from http://www.ojs.uma.ac.id/index.php/jppuma/article/view/909/916

Sitanggang, M. D., \& Husin, S. (2014). Persepsi masyarakat terhadap kinerja Camat dalam meningkatkan mutu pendidikan. Jurnal Ilmu Pemerintahan dan Sosial Politik, 2(1), 57-76. Retrieved from http://ojs.uma.ac.id/index.php/jppuma/article/view/581/925

Sudarmaji, \& Sari, A. (2016). Sistem informasi website dinamis sebagai media informasi pada Kantor Camat Bangunrejo Lampung Tengah. Mikrotik, 6(3), 1-20. Retrieved from https://ojs.ummetro.ac.id/index.php/mikrotik/article/view/302/242

Syafiie, I. K. (2013). Ilmu pemerintahan. Jakarta: Bumi Aksara.

Yusdianto, Y. (2015). Hubungan kewenangan Pusat dan Daerah menurut UndangUndang Nomor 23 Tahun 2014 tentang Pemerintahan Daerah. Padjadjaran Jurnal Ilmu Hukum, 2(3), 483-504. https://doi.org/10.22304/pjih.v2n3.a4

Yuswalina \& Budianto, K. (2016). Hukum tata negara di Indonesia. Malang: Setara Press.

Rusmanto. (2018). Camat Kecamatan Gringsing, Kabupaten Batang. An Interview. 